Published in final edited form as:

N Engl J Med. 2010 February 25; 362(8): 726-738. doi:10.1056/NEJMra0905750.

\title{
Graves' Ophthalmopathy
}

\author{
Rebecca S. Bahn, M.D. \\ Division of Endocrinology, Diabetes, Metabolism, and Nutrition, Mayo Clinic, Rochester, MN
}

\begin{abstract}
Graves' ophthalmopathy, also called Graves' orbitopathy, is a potentially sight-threatening ocular disease that has puzzled physicians and scientists for nearly two centuries. ${ }^{1-3}$ Generally occurring in patients with hyperthyroidism or a history of hyperthyroidism due to Graves' disease, Graves' ophthalmopathy is also known as thyroid-associated ophthalmopathy or thyroid eye disease, because it sometimes occurs in patients with euthyroid or hypothyroid chronic autoimmune thyroiditis. The condition has an annual adjusted incidence rate of 16 women and 3 men per 100,000 population. ${ }^{4}$

This review explores the perplexing relationship between Graves' ophthalmopathy, hyperthyroidism, and thyroid dermopathy, the associated skin condition. I examine clinical features, histologic findings, and laboratory studies, with an emphasis on mechanisms that could be targeted in the development of new treatments for this debilitating disease.
\end{abstract}

\section{CLINICAL AND LABORATORY FEATURES}

The close clinical and temporal relationships between hyperthyroidism, Graves' ophthalmopathy, and thyroid dermopathy suggest that these conditions evolve from a single underlying systemic process with variable expression in the thyroid, eyes, and skin. Bilateral ocular symptoms and hyperthyroidism most often occur simultaneously or within 18 months of each other, although occasionally Graves' ophthalmopathy precedes or follows the onset of hyperthyroidism by many years. ${ }^{5}$ Almost half of patients with Graves' hyperthyroidism report symptoms of Graves' ophthalmopathy, including a dry and gritty ocular sensation, photophobia, excessive tearing, double vision, and a pressure sensation behind the eyes. The most common clinical features of Graves' ophthalmopathy are upper eyelid retraction, edema, and erythema of the periorbital tissues and conjunctivae, and proptosis (Fig. 1). Approximately 3 to 5\% of patients with Graves' ophthalmopathy have severe disease with intense pain, inflammation, and sight-threatening corneal ulceration or compressive optic neuropathy. ${ }^{6}$ Subclinical eye involvement is common: in nearly $70 \%$ of adult patients with Graves' hyperthyroidism, magnetic resonance imaging or computed tomographic scanning reveals extraocular-muscle enlargement. ${ }^{7}$ Although clinically unilateral Graves' ophthalmopathy occurs occasionally, orbital imaging generally confirms the presence of asymmetric bilateral disease. ${ }^{8}$ Thyroid dermopathy (also called pretibial myxedema), a nodular or diffuse thickening of the pretibial skin, sometimes progresses to debilitating disease. Although diagnosed on physical examination in only $13 \%$ of patients with severe Graves' ophthalmopathy, subclinical involvement of the skin of the legs and other regions of the body occurs more commonly. ${ }^{9}$ Approximately $20 \%$ of patients with thyroid dermopathy have thyroid acropachy, which manifests as clubbing of the fingers and toes.

Copyright @ 2010 Massachusetts Medical Society.

Address reprint requests to Dr. Bahn at the Division of Endocrinology, Diabetes, Metabolism, and Nutrition, Mayo Clinic, 200 First St. SW, Rochester, MN 55905, or at bahn.rebecca@mayo.edu.

No potential conflict of interest relevant to this article was reported. 
Graves' hyperthyroidism is caused by autoantibodies that bind to the thyrotropin receptor on thyroid follicular endothelial cells and thereby stimulate excess production of thyroid hormone. ${ }^{10}$ The presence of anti-thyrotropin-receptor antibodies in virtually all patients with Graves' ophthalmopathy suggests that immunoreactivity against the thyrotropin receptor underlies both Graves' ophthalmopathy and hyperthyroidism. ${ }^{11}$ The $5 \%$ of patients with Graves' ophthalmopathy who are euthyroid or hypothyroid generally have low titers of anti-thyrotropin-receptor antibodies, which are difficult to detect in some assays. ${ }^{12}$ Levels of anti-thyrotropin-receptor antibodies correlate positively with clinical features of Graves' ophthalmopathy ${ }^{13}$ and influence the prognosis ${ }^{14}$; these antibody levels are especially elevated in patients with thyroid dermopathy. ${ }^{15}$

Cigarette smoking is the strongest modifiable risk factor for Graves' ophthalmopathy (odds ratio among smokers vs. nonsmokers, 7.7), and the risk is proportional to the number of cigarettes smoked daily. ${ }^{16}$ In smokers with Graves' ophthalmopathy, as compared with nonsmokers, severe disease is more likely to develop and is more likely to respond less well to immunosuppressive therapies. ${ }^{17}$ Smoking is associated with many autoimmune diseases, perhaps owing to nonspecific suppression of T-cell activation, reduction of natural killer $\mathrm{T}$ cells, and impairment of humoral and cell-mediated immunity. ${ }^{18}$ The strong association between Graves' ophthalmopathy and smoking suggests the involvement of additional factors, including direct effects of cigarette toxins ${ }^{19}$ and trauma from heat transmitted from the ethmoid sinuses through the lamina papyracea (the thin medial orbital wall).

\section{ANATOMICAL AND HISTOLOGIC FINDINGS}

Many clinical signs and symptoms of Graves' ophthalmopathy arise from soft-tissue enlargement in the orbit, leading to increased pressure within the bony cavity. ${ }^{20,21}$ Most patients have enlargement of both extraocular muscle and adipose tissue, with a predominance of one or the other in some (Fig. 2). ${ }^{22}$ Patients under 40 years of age tend to have fat expansion, whereas patients over 60 years of age have more extraocular-muscle swelling. ${ }^{23}$ In some patients, proptosis develops as the globe protrudes, decompressing the orbit. Patients with crowding of enlarged muscles at the orbital apex and minimal proptosis are at particular risk for compressive optic neuropathy.

Diplopia develops from inflammation and swelling of the extraocular muscles and is generally restrictive rather than paralytic. The inferior rectus is the most commonly involved muscle. Upper-eyelid retraction is caused by increased sympathetic stimulation of Müller's muscle, overaction of the levator muscle as it contracts against a tight inferior rectus, or scarring between the levator and surrounding tissues. Symptomatic corneal dryness is due to eyelid retraction, decreased blinking, increased tear evaporation, and incomplete eyelid closure during sleep.

Anatomical and mechanical features of the orbit and lower extremities may be important in expression of the disease. Periorbital edema is primarily congestive and most likely reflects decreased venous drainage due to vascular compression within the orbital space. Similarly, dependent edema after prolonged standing, when venous and lymphatic flow is compromised, can worsen thyroid dermopathy. ${ }^{24}$ Moreover, individual anatomical variability, such as the volume or shape of the orbits ${ }^{25}$ or variations in venous or lymphatic drainage, may increase the risk of extrathyroidal manifestations in patients with Graves' disease. In Graves' ophthalmopathy, trauma itself may be a stimulus; it has long been observed that thyroid dermopathy may develop at sites of trauma to the skin of the shoulders, arms, or other regions. ${ }^{9}$

Histologic studies of Graves' ophthalmopathy have focused on extraocular muscles, owing to their obvious enlargement in patients with the disease. However, electron microscopy 
reveals intact extraocular muscle fibers in such patients. ${ }^{26}$ The extraocular muscles are widely separated by an amorphous accumulation of granular material consisting primarily of collagen fibrils and glycosaminoglycans, among which hyaluronan predominates (Fig. 3). ${ }^{27}$ The polyanionic charge and extremely high osmotic pressure of this matrix substance make it extremely hydrophilic and capable of binding many times its weight in water.

Consequently, the muscle bodies become edematous and may enlarge to many times their normal size. In inactive disease, atrophy and fibrosis of muscle bundles are evident, with extension of fibrous strands into adjacent adipose tissues. Histologic features of thyroid dermopathy are similar to those seen in the orbit, with hyaluronan accumulation in the reticular dermis, although with less abundant lymphocytic infiltration and no evidence of fat expansion. ${ }^{9}$

Focal and diffuse mononuclear-cell infiltration occurs within the extraocular and levator muscles, lacrimal glands, and adipose tissues in active Graves' ophthalmopathy. ${ }^{28}$ These cells are primarily $\mathrm{CD} 4+\mathrm{T}$ cells, but there are also minor populations of CD8+ cells, B cells, plasma cells, and macrophages..$^{29,30}$ In early stages of the disease, type 1 helper T cells predominate and produce the cytokines interleukin-2, interferon- $\gamma$, and tumor necrosis factor (TNF), indicating ongoing cell-mediated immunity within the orbit. In disease of longer duration, type 2 helper $T$ cells that produce interleukin-4, interleukin-5, and interleukin-10 are dominant and propagate autoantibody production. ${ }^{31}$ Macrophages, fibroblasts, and adipocytes produce other inflammatory mediators, including interleukins 1,6 , and 16 and transforming growth factor $\beta$ (TGF- $\beta$ ) within the orbit. ${ }^{32,33}$

\section{CELLULAR ORIGINS}

Current evidence points to orbital fibroblasts as the target cells in Graves' ophthalmopathy and suggests that their normal functions are dysregulated through autoimmune mechanisms. ${ }^{34,35}$ The concept that fibroblast proteins are autoantigens in Graves' ophthalmopathy derives in part from the finding that orbital $\mathrm{T}$ cells obtained from patients with Graves' ophthalmopathy proliferate when exposed in vitro to autologous orbital fibroblast proteins. ${ }^{36}$ These orbital fibroblasts secrete large quantities of hyaluronan in response to various cytokines, ${ }^{34}$ and a subgroup of orbital fibroblasts can differentiate into mature adipocytes ${ }^{37}$ that have increased expression of thyrotropin receptor. ${ }^{38,39}$ These cellular changes lead to the characteristically enlarged eye muscles and expansion of orbital fat of patients with Graves' ophthalmopathy.

Orbital adipose tissue is a unique fat depot that supports and cushions the globe, extraocular muscles, and other orbital structures. Most orbital disorders are inflammatory, ${ }^{40}$ suggesting that orbital fat may be especially prone to robust inflammatory reactions. Indeed, as compared with fibroblasts from other sites, orbital fibroblasts show exaggerated inflammatory responses to various stimuli. ${ }^{41}$ Although orbital fibroblasts produce high levels of the proinflammatory cytokine interleukin-1, their expression of the neutralizing interleukin-1-receptor antagonist is relatively low. ${ }^{42}$ Likewise, orbital fibroblasts treated with interferon- $\gamma$ or leukoregulin synthesize particularly high levels of prostaglandin $E_{2}$, a mediator with important roles in inflammation. ${ }^{43}$

The orbit contains subpopulations of fibroblasts exhibiting phenotypic and functional heterogeneity. The cell-surface marker Thy-1 (CD90) is overexpressed in orbital tissues in Graves' ophthalmopathy ${ }^{44}$ and defines a population of fibroblasts capable of cytokineinduced production of prostaglandin $\mathrm{E}_{2}$, interleukin-8, and hyaluronan. ${ }^{45}$ When exposed to TGF- $\beta$, these fibroblasts differentiate into myofibroblasts with prominent cytoplasmic actin filaments that can participate in inflammation, repair, and fibrosis. Although fibroblasts within the extraocular muscles are almost exclusively Thy-1+, approximately half the 
fibroblasts within the adipose tissue lack this marker and are preadipocytes capable of differentiation into mature fat cells. Within the orbit, relative proportions of Thy-1+ and Thy-1- fibroblasts and their degree of exposure to TGF- $\beta$ may affect disease expression, including whether muscle or fat expansion predominates and the extent of fibrosis that develops. ${ }^{46}$

\section{MOLECULAR MECHANISMS}

Investigators have long postulated that the thyrotropin receptor is a target of autoimmunity within the orbit and that its recognition by a circulating thyrotropin-like factor explains the link between hyperthyroidism and Graves' ophthalmopathy. ${ }^{47-49}$ The cloning of the thyrotropin receptor ${ }^{50,51}$ enabled direct assessment of the expression of this receptor in extrathyroidal tissues, and several groups reported a low abundance of thyrotropin receptor in cultured orbital fibroblasts ${ }^{52-54}$ and in normal orbital-adipose tissues. ${ }^{55}$ Subsequent studies showed elevated thyrotropin-receptor expression in orbital tissues in patients with Graves' ophthalmopathy, ${ }^{39,56}$ with the highest levels in those with clinically active disease. ${ }^{57}$ These findings, along with the close association between Graves' ophthalmopathy and Graves' hyperthyroidism and the consistently elevated levels of anti-thyrotropinreceptor antibodies in Graves' ophthalmopathy, support the concept that the thyrotropin receptor is the primary autoantigen in Graves' ophthalmopathy (Fig. 4). A low abundance of thyrotropin receptor can also be detected in several extrathyroidal tissues, including skin, adrenal gland, kidney, and thymus. ${ }^{58-60}$ In the pretibial skin of patients with thyroid dermopathy, the level of the thyrotropin receptor is elevated. ${ }^{61}$

In animal models of Graves' disease, various methods have been used to induce the production of anti-thyrotropin-receptor antibodies, and the results have provided valuable insights into the pathogenesis of hyperthyroidism. ${ }^{62}$ However, reproducible ocular changes resembling those in Graves' ophthalmopathy have not been reported, ${ }^{63}$ perhaps owing partly to differences in orbital anatomy between humans and rodents. Similarly, much has been learned about the genetic basis of thyroid autoimmunity, but it is unclear whether there is a genetic susceptibility to Graves' ophthalmopathy apart from that identified for Graves' disease. ${ }^{64}$

Adipogenesis requires growth arrest and the induction of transcriptional regulators, including peroxisome-proliferator-activated receptor $\gamma(\operatorname{PPAR}-\gamma){ }^{65}$ Evidence that adipogenesis is active in the orbit in Graves' ophthalmopathy includes the results of microarray studies showing upregulation of immediate early adipogenic genes ${ }^{66}$ and other adipocyte-related genes, including those encoding PPAR- $\gamma$, interleukin- 6 , adiponectin, and leptin. ${ }^{67}$ PPAR- $\gamma$ agonists stimulate adipogenesis and expression of the thyrotropin receptor in cultured orbital preadipocytes. ${ }^{46,68}$ Several reports have described progressive proptosis in patients with a history of Graves' ophthalmopathy, as well as in those without such a history, after the treatment of type 2 diabetes mellitus with PPAR- $\gamma$ agonists of the thiazolidinedione type. ${ }^{69,70}$ Therefore, particular sensitivity to PPAR- $\gamma$ ligation may be a characteristic of orbital preadipocytes.

Factors that might stimulate adipogenesis within the orbit in patients with Graves' ophthalmopathy include naturally occurring PPAR- $\gamma$ ligands, which are proadipogenic prostaglandins produced by activated $\mathrm{T}$ cells through the activity of cyclooxygenase- $2 .{ }^{71}$ This enzyme is upregulated in the orbit of patients with Graves' ophthalmopathy, ${ }^{72}$ and T cells from such patients produce prostaglandins that induce adipogenesis in orbital fibroblasts. ${ }^{73}$ Thyrotropin can stimulate adipogenesis in mouse embryonic stem cells, even in the absence of other adipogenic factors, suggesting that activation of the thyrotropin receptor initiates new fat-cell development. ${ }^{74}$ In orbital fibroblasts that were transfected with 
an activating mutant thyrotropin-receptor construct, ${ }^{75,76}$ both early adipocyte differentiation and hyaluronan production were stimulated, suggesting that thyrotropin-receptor ligation by anti- thyrotropin-receptor antibodies within the orbit directly contributes to the soft-tissue changes characteristic of Graves' ophthalmopathy.

The type I insulin-like growth factor receptor (IGF-IR) may be another important autoantigen in Graves' ophthalmopathy. Orbital fibroblasts in patients with the disease express higher levels of IGF-IR than normal fibroblasts. ${ }^{77}$ In addition, the IgG fraction of pooled serum samples obtained from patients with Graves' disease contains autoantibodies that stimulate orbital fibroblasts from patients with Graves' ophthalmopathy to synthesize interleukin-16 and the chemokine RANTES (regulated upon activation normal T-cell expressed and secreted), factors that enhance trafficking of CD4+ T cells. ${ }^{78}$ This effect was inhibited by a specific monoclonal antibody that blocks IGF-IR and by transfecting fibroblasts with a dominant-negative mutant IGF-IR, suggesting that signaling through IGFIR mediates the process. Moreover, IgG from patients with Graves' disease stimulates hyaluronan synthesis by orbital fibroblasts from patients with Graves' ophthalmopathy but not by normal orbital-cell cultures. ${ }^{79}$ Tsui and colleagues ${ }^{80}$ have proposed that there are physical and functional relationships between IGF-IR and the thyrotropin receptor, as suggested by colocalization studies and the finding that a monoclonal antibody that specifically blocks IGF-IR inhibits thyrotropin-induced kinase signaling. Although a role for IGF-IR and antibodies targeting this receptor in Graves' ophthalmopathy is potentially important, it has yet to be confirmed by other investigators.

Orbital fibroblasts participate in the autoimmune process within the orbit in Graves' ophthalmopathy (Fig. 5). These cells express CD40, a costimulatory protein present on the surface of many types of cells, including macrophages, lymphocytes, and thyrocytes. ${ }^{81}$ CD4+ T cells expressing the CD40 ligand (also called CD154) directly activate orbital fibroblasts through the formation of CD40-CD154 bridges; as a result, such fibroblasts proliferate ${ }^{82}$ and produce high levels of interleukin- 1 and interleukin- $6 .{ }^{83}$ In addition, leukoregulin and interferon- $\gamma$ (products of activated T cells) and interleukin- 1 (secreted by resident fibroblasts and macrophages) increase the synthesis of hyaluronan and prostaglandin $E_{2}$ by orbital fibroblasts. ${ }^{84-86}$ Interleukin-1 and interferon- $\gamma$, as well as IgG obtained from patients with Graves' disease, can also stimulate orbital fibroblasts to express adhesion molecules that promote direct interaction between target cells and inflammatory cells.

The disease-producing effects of some soluble mediators within the orbit in Graves' ophthalmopathy are opposed by others that mitigate these effects. Interleukin-6, a product of activated T cells, macrophages, fibroblasts, and adipocytes, is proinflammatory and enhances B-cell differentiation and antibody production but also reduces the strength of many inflammatory activities of interleukin- $1 .{ }^{87}$ TGF- $\beta$, TNF, and interferon- $\gamma$ inhibit adipogenesis and thyrotropin-receptor expression in cultured orbital fibroblasts ${ }^{88}$ and thus may counteract PPAR- $\gamma$ ligation within the orbit. Although some endogenous PPAR- $\gamma$ ligands produced by activated $\mathrm{T}$ cells trigger adipocyte differentiation, ${ }^{73}$ others oppose inflammation by inhibiting production of inflammatory cytokines by macrophages, monocytes, and adipocytes. ${ }^{89}$ Finally, TGF- $\beta$ produced by fibroblasts most likely acts in an autocrine fashion to stimulate hyaluronan synthesis ${ }^{84}$ and the differentiation of the Thy-1+ subgroup of fibroblasts into myofibroblasts ${ }^{46}$ while it also inhibits adipogenesis in these cells. 


\section{THERAPEUTIC IMPLICATIONS}

Our understanding of Graves' ophthalmopathy points to several potential therapeutic targets and suggests difficulties in designing effective immunotherapy for this disease. ${ }^{90}$ The immune mediators that cause pathogenic orbital changes have additional roles within the adaptive immune network. Therefore, it is difficult to predict whether the biologic agents that are effective in, say, rheumatoid arthritis ${ }^{91}$ will be useful in treating Graves' ophthalmopathy. Answers will come from randomized clinical trials designed to account for the unique features of Graves' ophthalmopathy, such as the self-limited duration of active disease and the central role of tissue expansion rather than destruction.

Agents that neutralize cytokine-induced inflammation or production of hyaluronan by orbital fibroblasts, such as anti-TNF agents ${ }^{92}$ and agents targeting the interleukin-1 receptor $^{93}$ or the interleukin- 6 receptor ${ }^{94}$ (Table 1), are attractive potential treatments for Graves' ophthalmopathy. Targeting TNF in patients with Graves' ophthalmopathy might affect the production by preadipocytes of chemoattractant protein 1, a macrophage-attracting protein. ${ }^{113}$ The findings of a case report ${ }^{95}$ and a small, open study ${ }^{96}$ should encourage the performance of randomized trials of anti-TNF therapy in patients with Graves' ophthalmopathy. Antioxidants such as selenium may be useful, since they have a beneficial effect on autoimmunity in Graves' disease. ${ }^{101}$ Neutralizing the profibrotic effects of TGF- $\beta$ may also be of benefit, especially in patients with inactive Graves' ophthalmopathy, in whom countering the antiinflammatory and antiadipogenic effects of this cytokine may be less detrimental than in those with the active disease. ${ }^{100}$

Targeting autoreactive B cells with rituximab, an anti-CD20 monoclonal antibody, is another possible approach. ${ }^{114}$ In a study of Graves' hyperthyroidism, rituximab decreased the total anti- thyrotropin-receptor antibody levels only minimally but markedly reduced $(66 \%)$ the subgroup of stimulatory anti-thyrotropin-receptor antibodies. ${ }^{115}$ Several case reports have suggested that rituximab might be effective in active Graves' ophthalmopathy, ${ }^{103,116}$ and randomized, controlled trials of this agent in Graves' ophthalmopathy are being led by Bahn ${ }^{117}$ and Salvi (Salvi M: personal communication). The important role of cellular immunity in Graves' ophthalmopathy suggests that targeting CD3 on T cells ${ }^{106}$ may hold promise. Similarly, inhibitors of the cellular interactions necessary for T-cell signaling, which potentially decrease production of both autoantibodies and inflammatory cytokines, may be of benefit. ${ }^{107} \mathrm{~A}$ recent study of a mouse model of Graves' disease showed that pretreatment with the thyrotropin receptor-A-subunit protein, before immunization with an adenovirus bearing the same subunit, attenuated subsequent hyperthyroidism by directing the autoantibody response away from pathogenic epitopes. ${ }^{118}$ Although administration of the subunit did not reverse established hyperthyroidism, tolerance to particular thyrotropin-receptor epitopes was achieved; therefore, this approach may be useful for disease prevention in predisposed persons.

\section{CONCLUSIONS}

Although recent studies suggest that there are novel mechanisms involved in the development of Graves' ophthalmopathy, much remains to be learned. The thyrotropin receptor on orbital fibroblasts is likely to be an important autoimmune target in the disease, and early evidence suggests that immunoreactivity directed against IGF-IR may also be involved. Many studies support a role for cellular immunity, and recent findings suggest that autoantibodies may also directly affect the orbital disease process. The recent demonstration that some anti-thyrotropin-receptor antibodies signal within the thyrocyte through a unique signaling cascade not used by thyrotropin suggests that various antibodies may activate somewhat different signaling networks. ${ }^{119}$ It is therefore possible that various clinical 
phenotypes, such as euthyroid Graves' ophthalmopathy or the predominance of muscle or fat enlargement, may be affected by the molecular signature of the particular antithyrotropin-receptor antibodies or other autoantibodies produced. Delineation of the functional heterogeneity of anti-thyrotropin-receptor antibodies and the signaling pathways involved will improve our understanding of orbital disease mechanisms and may suggest new approaches to therapy, including perhaps the use of low-molecular-weight thyrotropinreceptor antagonists. ${ }^{112}$

Unraveling the Graves' ophthalmopathy conundrum would enable the design of effective means of prevention or treatment. The quality of life is markedly decreased in patients with Graves' ophthalmopathy, ${ }^{120}$ and now we have the means to precisely measure the effect of new therapies on quality of life and specific clinical end points. The recent, excellent consensus statement on therapy for Graves' ophthalmopathy developed by the European Group on Graves' Orbitopathy ${ }^{121}$ emphasizes the importance of performing randomized, controlled, multicenter trials of current treatments and new therapies on the horizon. These might be tailored to specific disease phenotypes or stages and use combination therapies to improve outcomes. Although major challenges remain, patients with Graves' ophthalmopathy should benefit from these efforts.

\section{Acknowledgments}

Supported in part by a grant from the National Institute of Diabetes and Digestive and Kidney Diseases (DK77814).

I thank Drs. Michael Brennan, Marius Stan, James Garrity, and George Bartley for their review of the manuscript and very helpful suggestions; the members of my laboratory who have studied Graves' ophthalmopathy with me over many years; and the patients with this disease who have taught me so much.

\section{References}

1. Graves R. Newly observed affection of the thyroid: clinical lectures. Lond Med Surg J. 1835; 7:516-7.

2. Parry C. Diseases of the heart. Elements Pathol Ther. 1825; 2:111-28.

3. von Basedow K. Exophthalmos durch hypertrophie des zellgewebes in der augenhöhle. Wochenschr Heilkunde. 1840; 6:197-204.

4. Bartley GB. The epidemiologic characteristics and clinical course of ophthalmopathy associated with autoimmune thyroid disease in Olmsted County, Minnesota. Trans Am Ophthalmol Soc. 1994; 92:477-588. [PubMed: 7886878]

5. Wiersinga WM, Smit T, van der Gaag R, Koornneef L. Temporal relationship between onset of Graves' ophthalmopathy and onset of thyroidal Graves' disease. J Endocrinol Invest. 1988; 11:6159. [PubMed: 2907524]

6. Wiersinga WM, Bartalena L. Epidemiology and prevention of Graves' ophthalmopathy. Thyroid. 2002; 12:855-60. [PubMed: 12487767]

7. Enzmann DR, Donaldson SS, Kriss JP. Appearance of Graves' disease on orbital computed tomography. J Comput Assist Tomogr. 1979; 3:815-9. [PubMed: 583152]

8. Wiersinga WM, Smit T, van der Gaag R, Mourits M, Koornneef L. Clinical presentation of Graves' ophthalmopathy. Ophthalmic Res. 1989; 21:73-82. [PubMed: 2786616]

9. Fatourechi V. Pretibial myxedema: pathophysiology and treatment options. Am J Clin Dermatol. 2005; 6:295-309. [PubMed: 16252929]

10. Rapoport B, McLachlan SM. The thyrotropin receptor in Graves' disease. Thyroid. 2007; 17:91122. [PubMed: 17822379]

11. Khoo DH, Eng PH, Ho SC, et al. Graves' ophthalmopathy in the absence of elevated free thyroxine and triiodothyronine levels: prevalence, natural history, and thyrotropin receptor antibody levels. Thyroid. 2000; 10:1093-100. [PubMed: 11201855] 
12. Eckstein AK, Lösch C, Glowacka D, et al. Euthyroid and primarily hypothyroid patients develop milder and significantly more asymmetrical Graves ophthalmopathy. Br J Ophthalmol. 2009; 93:1052-6. [PubMed: 19221109]

13. Gerding MN, van der Meer JW, Broenink M, Bakker O, Wiersinga WM, Prummel MF. Association of thyrotrophin receptor antibodies with the clinical features of Graves' ophthalmopathy. Clin Endocrinol (Oxf). 2000; 52:267-71. [PubMed: 10718823]

14. Eckstein AK, Plicht M, Lax H, et al. Thyrotropin receptor autoantibodies are independent risk factors for Graves' ophthalmopathy and help to predict severity and outcome of the disease. J Clin Endocrinol Metab. 2006; 91:3464-70. [PubMed: 16835285]

15. Morris JC III, Hay ID, Nelson RE, Jiang NS. Clinical utility of thyrotropin-receptor antibody assays: comparison of radioreceptor and bioassay methods. Mayo Clin Proc. 1988; 63:707-17. [PubMed: 2898572]

16. Prummel MF, Wiersinga WM. Smoking and risk of Graves' disease. JAMA. 1993; 269:479-82. [PubMed: 8419666]

17. Bartalena L, Pinchera A, Marcocci C. Management of Graves' ophthalmopathy: reality and perspectives. Endocr Rev. 2000; 21:168-99. [PubMed: 10782363]

18. Costenbader KH, Karlson EW. Cigarette smoking and autoimmune disease: what can we learn from epidemiology? Lupus. 2006; 15:737-45. [PubMed: 17153844]

19. Cawood TJ, Moriarty P, O'Farrelly C, O'Shea D. Smoking and thyroid-associated ophthalmopathy: a novel explanation of the biological link. J Clin Endocrinol Metab. 2007; 92:5964. [PubMed: 17047020]

20. Bahn RS, Heufelder AE. Pathogenesis of Graves' ophthalmopathy. N Engl J Med. 1993; 329:1468-75. [PubMed: 8413459]

21. Otto AJ, Koornneef L, Mourits MP, Deen-van Leeuwen L. Retrobulbar pressures measured during surgical decompression of the orbit. Br J Ophthalmol. 1996; 80:1042-5. Erratum, Br J Ophthalmol 1997;81:175. [PubMed: 9059266]

22. Forbes G, Gorman CA, Brennan MD, Gehring DG, Ilstrup DM, Earnest F IV. Ophthalmopathy of Graves' disease: computerized volume measurements of the orbital fat and muscle. AJNR Am J Neuroradiol. 1986; 7:651-6. [PubMed: 3088943]

23. Anderson RL, Tweeten JP, Patrinely JR, Garland PE, Thiese SM. Dysthyroid optic neuropathy without extraocular muscle involvement. Ophthalmic Surg. 1989; 20:568-74. [PubMed: 2779967]

24. Rapoport B, Alsabeh R, Aftergood D, McLachlan SM. Elephantiasic pretibial myxedema: insight into and a hypothesis regarding the pathogenesis of the extrathyroidal manifestations of Graves' disease. Thyroid. 2000; 10:685-92. [PubMed: 11014313]

25. Chan LL, Tan HE, Fook-Chong S, Teo TH, Lim LH, Seah LL. Graves ophthalmopathy: the bony orbit in optic neuropathy, its apical angular capacity, and impact on prediction of risk. AJNR Am J Neuroradiol. 2009; 30:597-602. [PubMed: 19147718]

26. Kroll AJ, Kuwabara T. Dysthyroid ocular myopathy: anatomy, histology, and electron microscopy. Arch Ophthalmol. 1966; 76:244-7. [PubMed: 5945177]

27. Smith TJ, Bahn RS, Gorman CA. Connective tissue, glycosaminoglycans, and diseases of the thyroid. Endocr Rev. 1989; 10:366-91. [PubMed: 2673756]

28. Riley FC. Orbital pathology in Graves' disease. Mayo Clin Proc. 1972; 47:975-9.

29. Pappa A, Calder V, Ajjan R, et al. Analysis of extraocular muscle-infiltrating T cells in thyroidassociated ophthalmopathy (TAO). Clin Exp Immunol. 1997; 109:362-9. [PubMed: 9276534]

30. Eckstein AK, Quadbeck B, Tews S, et al. Thyroid associated ophthalmopathy: evidence for CD4(+) $\gamma \delta$ T cells, de novo differentiation of RFD7(+) macrophages, but not of RFD1(+) dendritic cells, and loss of $\gamma \delta$ and $\alpha \beta$ T cell receptor expression. Br J Ophthalmol. 2004; 88:803-8. [PubMed: 15148216]

31. Aniszewski JP, Valyasevi RW, Bahn RS. Relationship between disease duration and predominant orbital T cell subset in Graves' ophthalmopathy. J Clin Endocrinol Metab. 2000; 85:776-80. [PubMed: 10690890]

32. Kumar S, Bahn RS. Relative overexpression of macrophage-derived cytokines in orbital adipose tissue from patients with Graves' ophthalmopathy. J Clin Endocrinol Metab. 2003; 88:4246-50. [PubMed: 12970294] 
33. Hiromatsu Y, Yang D, Bednarczuk T, Miyake I, Nonaka K, Inoue Y. Cytokine profiles in eye muscle tissue and orbital fat tissue from patients with thyroid-associated ophthalmopathy. J Clin Endocrinol Metab. 2000; 85:1194-9. [PubMed: 10720061]

34. Prabhakar BS, Bahn RS, Smith TJ. Current perspective on the pathogenesis of Graves' disease and ophthalmopathy. Endocr Rev. 2003; 24:802-35. [PubMed: 14671007]

35. Bahn RS. Clinical review 157: pathophysiology of Graves' ophthalmopathy: the cycle of disease. J Clin Endocrinol Metab. 2003; 88:1939-46. [PubMed: 12727937]

36. Otto EA, Ochs K, Hansen C, Wall JR, Kahaly GJ. Orbital tissue-derived T lymphocytes from patients with Graves' ophthalmopathy recognize autologous orbital antigens. J Clin Endocrinol Metab. 1996; 81:3045-50. [PubMed: 8768872]

37. Sorisky A, Pardasani D, Gagnon A, Smith TJ. Evidence of adipocyte differentiation in human orbital fibroblasts in primary culture. J Clin Endocrinol Metab. 1996; 81:3428-31. [PubMed: 8784110]

38. Valyasevi RW, Erickson DZ, Harteneck DA, et al. Differentiation of human orbital preadipocyte fibroblasts induces expression of functional thyrotropin receptor. J Clin Endocrinol Metab. 1999; 84:2557-62. [PubMed: 10404836]

39. Starkey KJ, Janezic A, Jones G, Jordan N, Baker G, Ludgate M. Adipose thyrotrophin receptor expression is elevated in Graves' and thyroid eye diseases ex vivo and indicates adipogenesis in progress in vivo. J Mol Endocrinol. 2003; 30:369-80. [PubMed: 12790806]

40. Rootman, J. Pathophysiologic patterns of orbital disease. In: Rootman, J., editor. Diseases of the orbit: a multidisciplinary approach. 2. Philadelphia: Lippincott Williams \& Wilkins; 2003. p. 43-51.

41. Smith TJ, Tsai CC, Shih MJ, et al. Unique attributes of orbital fibroblasts and global alterations in IGF-1 receptor signaling could explain thyroid-associated ophthalmopathy. Thyroid. 2008; 18:983-8. [PubMed: 18788919]

42. Cao HJ, Han R, Smith TJ. Robust induction of PGHS-2 by IL-1 in orbital fibroblasts results from low levels of IL-1 receptor antagonist expression. Am J Physiol Cell Physiol. 2003; 284:C1429_ C1437. [PubMed: 12519748]

43. Smith TJ. The putative role of prostaglandin endoperoxide $\mathrm{H}$ synthase- 2 in the pathogenesis of thyroid-associated orbitopathy. Exp Clin Endocrinol Diabetes. 1999; 107(Suppl 5):S160-S163. [PubMed: 10614912]

44. Khoo TK, Coenen MJ, Schiefer AR, Kumar S, Bahn RS. Evidence for enhanced Thy-1 (CD90) expression in orbital fibroblasts of patients with Graves' ophthalmopathy. Thyroid. 2008; 18:1291-6. [PubMed: 18976167]

45. Koumas L, Smith TJ, Feldon S, Blumberg N, Phipps RP. Thy-1 expression in human fibroblast subsets defines myofibroblastic or lipofibroblastic phenotypes. Am J Pathol. 2003; 163:1291-300. [PubMed: 14507638]

46. Smith TJ, Koumas L, Gagnon A, et al. Orbital fibroblast heterogeneity may determine the clinical presentation of thyroid-associated ophthalmopathy. J Clin Endocrinol Metab. 2002; 87:385-92. [PubMed: 11788681]

47. Dobyns BM. Present concepts of the pathologic physiology of exophthalmos. J Clin Endocrinol Metab. 1950; 10:1202-30. [PubMed: 14794748]

48. Mullin BR, Lee G, Ledley FD, Winland RJ, Kohn LD. Thyrotropin interactions with human fat cell membrane preparations and the finding of soluble thyrotropin binding component. Biochem Biophys Res Commun. 1976; 69:55-62. [PubMed: 177020]

49. Davies TF, Teng CS, McLachlan SM, Smith BR, Hall R. Thyrotropin receptors in adipose tissue, retro-orbital tissue and lymphocytes. Mol Cell Endocrinol. 1978; 9:303-10. [PubMed: 203502]

50. Parmentier M, Libert F, Maenhaut C, et al. Molecular cloning of the thyrotropin receptor. Science. 1989; 246:1620-2. [PubMed: 2556796]

51. Nagayama Y, Kaufman KD, Seto P, Rapoport B. Molecular cloning, sequence and functional expression of the cDNA for the human thyrotropin receptor. Biochem Biophys Res Commun. 1989; 165:1184-90. [PubMed: 2558651] 
52. Heufelder AE, Dutton CM, Sarkar G, Donovan KA, Bahn RS. Detection of TSH receptor RNA in cultured fibroblasts from patients with Graves' ophthalmopathy and pretibial dermopathy. Thyroid. 1993; 3:297-300. [PubMed: 7509671]

53. Mengistu M, Lukes YG, Nagy EV, et al. TSH receptor gene expression in retroocular fibroblasts. J Endocrinol Invest. 1994; 17:437-41. [PubMed: 7523481]

54. Crisp MS, Lane C, Halliwell M, Wynford-Thomas D, Ludgate M. Thyrotropin receptor transcripts in human adipose tissue. J Clin Endocrinol Metab. 1997; 82:2003-5. [PubMed: 9177421]

55. Feliciello A, Porcellini A, Ciullo I, Bonavolonta G, Avvedimento EV, Fenzi G. Expression of thyrotropin-receptor mRNA in healthy and Graves' disease retro-orbital tissue. Lancet. 1993; 342:337-8. [PubMed: 8101586]

56. Bahn RS, Dutton CM, Natt N, Joba W, Spitzweg C, Heufelder AE. Thyrotropin receptor expression in Graves' orbital adipose/connective tissues: potential autoantigen in Graves' ophthalmopathy. J Clin Endocrinol Metab. 1998; 83:998-1002. [PubMed: 9506762]

57. Wakelkamp IM, Bakker O, Baldeschi L, Wiersinga WM, Prummel MF. TSH-R expression and cytokine profile in orbital tissue of active vs. inactive Graves' ophthalmopathy patients. Clin Endocrinol (Oxf). 2003; 58:280-7. [PubMed: 12608932]

58. Endo T, Ohno M, Kotani S, Gunji K, Onaya T. Thyrotropin receptor in nonthyroid tissues. Biochem Biophys Res Commun. 1993; 190:774-9. [PubMed: 8439328]

59. Dutton CM, Joba W, Spitzweg C, Heufelder AE, Bahn RS. Thyrotropin receptor expression in adrenal, kidney, and thymus. Thyroid. 1997; 7:879-84. [PubMed: 9459631]

60. Paschke R, Metcalfe A, Alcalde L, Vassart G, Weetman A, Ludgate M. Presence of nonfunctional thyrotropin receptor variant transcripts in retroocular and other tissues. J Clin Endocrinol Metab. 1994; 79:1234-8. [PubMed: 7962314]

61. Daumerie C, Ludgate M, Costagliola S, Many MC. Evidence for thyrotropin receptor immunoreactivity in pretibial connective tissue from patients with thyroid-associated dermopathy. Eur J Endocrinol. 2002; 146:35-8. [PubMed: 11751064]

62. McLachlan SM, Nagayama Y, Rapoport B. Insight into Graves' hyperthyroidism from animal models. Endocr Rev. 2005; 26:800-32. [PubMed: 15827111]

63. Baker G, Mazziotti G, von Ruhland C, Ludgate M. Reevaluating thyrotropin receptor-induced mouse models of Graves' disease and ophthalmopathy. Endocrinology. 2005; 146:835-44. [PubMed: 15542454]

64. Bednarczuk T, Gopinath B, Ploski R, Wall JR. Susceptibility genes in Graves' ophthalmopathy: searching for a needle in a haystack? Clin Endocrinol (Oxf). 2007; 67:3-19. [PubMed: 17521325]

65. Rosen ED, MacDougald OA. Adipocyte differentiation from the inside out. Nat Rev Mol Cell Biol. 2006; 7:885-96. [PubMed: 17139329]

66. Lantz M, Vondrichova T, Parikh H, et al. Overexpression of immediate early genes in active Graves' ophthalmopathy. J Clin Endocrinol Metab. 2005; 90:4784-91. [PubMed: 15928252]

67. Kumar S, Leontovich A, Coenen MJ, Bahn RS. Gene expression profiling of orbital adipose tissue from patients with Graves' ophthalmopathy: a potential role for secreted frizzled-related protein-1 in orbital adipogenesis. J Clin Endocrinol Metab. 2005; 90:4730-5. [PubMed: 15886250]

68. Valyasevi RW, Harteneck DA, Dutton CM, Bahn RS. Stimulation of adipogenesis, peroxisome proliferator-activated receptor- $\gamma(\operatorname{PPAR} \gamma)$, and thyrotropin receptor by $\operatorname{PPAR} \gamma$ agonist in human orbital preadipocyte fibroblasts. J Clin Endocrinol Metab. 2002; 87:2352-8. [PubMed: 11994387]

69. Starkey K, Heufelder A, Baker G, et al. Peroxisome proliferator-activated receptor-gamma in thyroid eye disease: contraindication for thiazolidinedione use? J Clin Endocrinol Metab. 2003; 88:55-9. [PubMed: 12519830]

70. Dorkhan M, Lantz M, Frid A, Groop L, Hallengren B. Treatment with a thiazolidinedione increases eye protrusion in a subgroup of patients with type 2 diabetes. Clin Endocrinol (Oxf). 2006; 65:35-9. [PubMed: 16817816]

71. Forman BM, Tontonoz P, Chen J, Brun RP, Spiegelman BM, Evans RM. 15-Deoxydelta 12, 14 prostaglandin $\mathrm{J} 2$ is a ligand for the adipocyte determination factor PPAR gamma. Cell. 1995; 83:803-12. [PubMed: 8521497] 
72. Konuk EB, Konuk O, Misirlioglu M, Menevse A, Unal M. Expression of cyclo-oxygenase-2 in orbital fibroadipose connective tissues of Graves' ophthalmopathy patients. Eur J Endocrinol. 2006; 155:681-5. [PubMed: 17062883]

73. Feldon SE, O'Loughlin CW, Ray DM, Landskroner-Eiger S, Seweryniak KE, Phipps RP. Activated human T lymphocytes express cyclooxygenase- 2 and produce proadipogenic prostaglandins that drive human orbital fibroblast differentiation to adipocytes. Am J Pathol. 2006; 169:1183-93. [PubMed: 17003477]

74. Lu M, Lin RY. TSH stimulates adipogenesis in mouse embryonic stem cells. J Endocrinol. 2008; 196:159-69. [PubMed: 18180327]

75. Zhang L, Baker G, Janus D, Paddon CA, Fuhrer D, Ludgate M. Biological effects of thyrotropin receptor activation on human orbital preadipocytes. Invest Ophthalmol Vis Sci. 2006; 47:5197203. [PubMed: 17122103]

76. Zhang L, Bowen T, Grennan-Jones F, et al. Thyrotropin receptor activation increases hyaluronan production in preadipocyte fibroblasts: contributory role in hyaluronan accumulation in thyroid dysfunction. J Biol Chem. 2009; 284:26447-55. [PubMed: 19633293]

77. Smith TJ. The putative role of fibroblasts in the pathogenesis of Graves' disease: evidence for the involvement of the insulin-like growth factor-1 receptor in fibroblast activation. Autoimmunity. 2003; 36:409-15. [PubMed: 14669949]

78. Pritchard J, Han R, Horst N, Cruikshank WW, Smith TJ. Immunoglobulin activation of T cell chemoattractant expression in fibroblasts from patients with Graves' disease is mediated through the insulin-like growth factor I receptor pathway. J Immunol. 2003; 170:6348-54. [PubMed: 12794168]

79. Smith TJ, Hoa N. Immunoglobulins from patients with Graves' disease induce hyaluronan synthesis in their orbital fibroblasts through the self-antigen, insulin-like growth factor-I receptor. J Clin Endocrinol Metab. 2004; 89:5076-80. [PubMed: 15472208]

80. Tsui S, Naik V, Hoa N, et al. Evidence for an association between thyroid-stimulating hormone and insulin-like growth factor 1 receptors: a tale of two antigens implicated in Graves' disease. J Immunol. 2008; 181:4397-405. [PubMed: 18768899]

81. Grewal IS, Flavell RA. The role of CD40 ligand in costimulation and T-cell activation. Immunol Rev. 1996; 153:85-106. [PubMed: 9010720]

82. Feldon SE, Park DJ, O'Loughlin CW, et al. Autologous T-lymphocytes stimulate proliferation of orbital fibroblasts derived from patients with Graves' ophthalmopathy. Invest Ophthalmol Vis Sci. 2005; 46:3913-21. [PubMed: 16249464]

83. Sempowski GD, Rozenblit J, Smith TJ, Phipps RP. Human orbital fibroblasts are activated through CD40 to induce pro-inflammatory cytokine production. Am J Physiol. 1998; 274:C707-C714. [PubMed: 9530102]

84. Korducki JM, Loftus SJ, Bahn RS. Stimulation of glycosaminoglycan production in cultured human retroocular fibroblasts. Invest Ophthalmol Vis Sci. 1992; 33:2037-42. [PubMed: 1582808]

85. Smith TJ, Wang HS, Evans CH. Leukoregulin is a potent inducer of hyaluronan synthesis in cultured human orbital fibroblasts. Am J Physiol. 1995; 268:C382-C388. [PubMed: 7864077]

86. Wang HS, Cao HJ, Winn VD, et al. Leukoregulin induction of prostaglandin-endoperoxide $\mathrm{H}$ synthase-2 in human orbital fibroblasts: an in vitro model for connective tissue inflammation. J Biol Chem. 1996; 271:22718-28. [PubMed: 8798446]

87. Nordan RP, Potter M. A macrophage-derived factor required by plasmacytomas for survival and proliferation in vitro. Science. 1986; 233:566-9. [PubMed: 3726549]

88. Valyasevi RW, Jyonouchi SC, Dutton CM, Munsakul N, Bahn RS. Effect of tumor necrosis factoralpha, interferon-gamma, and transforming growth factor-beta on adipogenesis and expression of thyrotropin receptor in human orbital preadipocyte fibroblasts. J Clin Endocrinol Metab. 2001; 86:903-8. [PubMed: 11158064]

89. Daynes RA, Jones DC. Emerging roles of PPARs in inflammation and immunity. Nat Rev Immunol. 2002; 2:748-59. [PubMed: 12360213]

90. Feldmann M, Steinman L. Design of effective immunotherapy for human autoimmunity. Nature. 2005; 435:612-9. [PubMed: 15931214] 
91. Olsen NJ, Stein CM. New drugs for rheumatoid arthritis. N Engl J Med. 2004; 350:2167-79. [PubMed: 15152062]

92. Feldmann M. Development of anti-TNF therapy for rheumatoid arthritis. Nat Rev Immunol. 2002; 2:364-71. [PubMed: 12033742]

93. Dinarello CA. The role of the interleukin-1-receptor antagonist in blocking inflammation mediated by interleukin-1. N Engl J Med. 2000; 343:732-4. [PubMed: 10974140]

94. Nishimoto N, Kishimoto T. Interleukin 6: from bench to bedside. Nat Clin Pract Rheumatol. 2006; 2:619-26. Erratum, Nat Clin Pract Rheumatol 2006;2:691. [PubMed: 17075601]

95. Durrani OM, Reuser TQ, Murray PI. Infliximab: a novel treatment for sight-threatening thyroid associated ophthalmopathy. Orbit. 2005; 24:117-9. [PubMed: 16191800]

96. Paridaens D, van den Bosch WA, van der Loos TL, Krenning EP, van Hagen PM. The effect of etanercept on Graves' ophthalmopathy: a pilot study. Eye (Lond). 2005; 19:1286-9. [PubMed: 15550932]

97. Mertens M, Singh JA. Anakinra for rheumatoid arthritis: a systematic review. J Rheumatol. 2009; 36:1118-25. [PubMed: 19447938]

98. Tan GH, Dutton CM, Bahn RS. Interleukin-1 (IL-1) receptor antagonist and soluble IL-1 receptor inhibit IL-1-induced glycosaminoglycan production in cultured human orbital fibroblasts from patients with Graves' ophthalmopathy. J Clin Endocrinol Metab. 1996; 81:449-52. [PubMed: 8636247]

99. Smolen JS, Beaulieu A, Rubbert-Roth A, et al. Effect of interleukin-6 receptor inhibition with tocilizumab in patients with rheumatoid arthritis (OPTION study): a double-blind, placebocontrolled, randomised trial. Lancet. 2008; 371:987-97. [PubMed: 18358926]

100. Pohlers D, Brenmoehl J, Löffler I, et al. TGF-beta and fibrosis in different organs - molecular pathway imprints. Biochim Biophys Acta. 2009; 1792:746-56. [PubMed: 19539753]

101. Wertenbruch T, Willenberg HS, Sagert C, et al. Serum selenium levels in patients with remission and relapse of Graves' disease. Med Chem. 2007; 3:281-4. [PubMed: 17504200]

102. Tsokos GC. B cells, be gone - B-cell depletion in the treatment of rheumatoid arthritis. N Engl J Med. 2004; 350:2546-8. [PubMed: 15201410]

103. El Fassi D, Nielsen CH, Hasselbalch HC, Hegedüs L. Treatment-resistant severe, active Graves' ophthalmopathy successfully treated with B lymphocyte depletion. Thyroid. 2006; 16:709-10. [PubMed: 16889501]

104. Kwan-Morley J, Albert D. B-cell inhibitors as therapy for rheumatoid arthritis: an update. Curr Rheumatol Rep. 2007; 9:401-6. [PubMed: 17915096]

105. Salvi M, Vannucchi G, Campi I, et al. Treatment of Graves' disease and associated ophthalmopathy with the anti-CD20 monoclonal antibody rituximab: an open study. Eur J Endocrinol. 2007; 156:33-40. [PubMed: 17218723]

106. Keymeulen B, Vandemeulebroucke E, Ziegler AG, et al. Insulin needs after CD3-antibody therapy in new-onset type 1 diabetes. N Engl J Med. 2005; 352:2598-608. [PubMed: 15972866]

107. Kremer JM, Westhovens R, Leon M, et al. Treatment of rheumatoid arthritis by selective inhibition of T-cell activation with fusion protein CTLA4Ig. N Engl J Med. 2003; 349:1907-15. [PubMed: 14614165]

108. Kalunian KC, Davis JC Jr, Merrill JT, Totoritis MC, Wofsy D. IDEC-131 Lupus Study Group. Treatment of systemic lupus erythematosus by inhibition of $\mathrm{T}$ cell costimulation with antiCD154: a randomized, double-blind, placebo-controlled trial. Arthritis Rheum. 2002; 46:3251-8. [PubMed: 12483729]

109. Knouff C, Auwerx J. Peroxisome proliferator-activated receptor-gamma calls for activation in moderation: lessons from genetics and pharmacology. Endocr Rev. 2004; 25:899-918. [PubMed: 15583022]

110. Straus DS, Glass CK. Anti-inflammatory actions of PPAR ligands: new insights on cellular and molecular mechanisms. Trends Immunol. 2007; 28:551-8. [PubMed: 17981503]

111. Cozma I, Zhang L, Uddin J, Lane C, Rees A, Ludgate M. Modulation of expression of somatostatin receptor subtypes in Graves' ophthalmopathy orbits: relevance to novel analogs. Am J Physiol Endocrinol Metab. 2007; 293:E1630-E1635. [PubMed: 17848636] 
112. Neumann S, Kleinau G, Costanzi S, et al. A low-molecular-weight antagonist for the human thyrotropin receptor with therapeutic potential for hyperthyroidism. Endocrinology. 2008; 149:5945-50. [PubMed: 18669595]

113. Wellen KE, Hotamisligil GS. Obesity-induced inflammatory changes in adipose tissue. J Clin Invest. 2003; 112:1785-8. [PubMed: 14679172]

114. Edwards JC, Cambridge G. B-cell targeting in rheumatoid arthritis and other autoimmune diseases. Nat Rev Immunol. 2006; 6:394-403. [PubMed: 16622478]

115. El Fassi D, Banga JP, Gilbert JA, Padoa C, Hegedüs L, Nielsen CH. Treatment of Graves' disease with rituximab specifically reduces the production of thyroid stimulating autoantibodies. Clin Immunol. 2009; 130:252-8. [PubMed: 18964302]

116. Salvi M, Vannucchi G, Campi I, et al. Rituximab treatment in a patient with severe thyroidassociated ophthalmopathy: effects on orbital lymphocytic infiltrates. Clin Immunol. 2009; 131:360-5. [PubMed: 19195932]

117. ClinicalTrials.gov. [Accessed January 21, 2010] Trial of rituximab for Graves' ophthalmopathy. at http://clinicaltrials.gov/ct2/show/NCT00595335

118. Misharin AV, Nagayama Y, Aliesky HA, Mizutori Y, Rapoport B, McLachlan SM. Attenuation of induced hyperthyroidism in mice by pretreatment with thyrotropin receptor protein: deviation of thyroid-stimulating to nonfunctional antibodies. Endocrinology. 2009; 150:3944-52. [PubMed: 19389831]

119. Morshed SA, Latif R, Davies TF. Characterization of thyrotropin receptor antibody-induced signaling cascades. Endocrinology. 2009; 150:519-29. [PubMed: 18719020]

120. Terwee C, Wakelkamp I, Tan S, Dekker F, Prummel MF, Wiersinga W. Long-term effects of Graves' ophthalmopathy on health-related quality of life. Eur J Endocrinol. 2002; 146:751-7. [PubMed: 12039694]

121. Bartalena L, Baldeschi L, Dickinson AJ, et al. Consensus statement of the European Group on Graves' Orbitopathy (EUGOGO) on management of Graves' orbitopathy. Thyroid. 2008; 18:333-46. [PubMed: 18341379] 

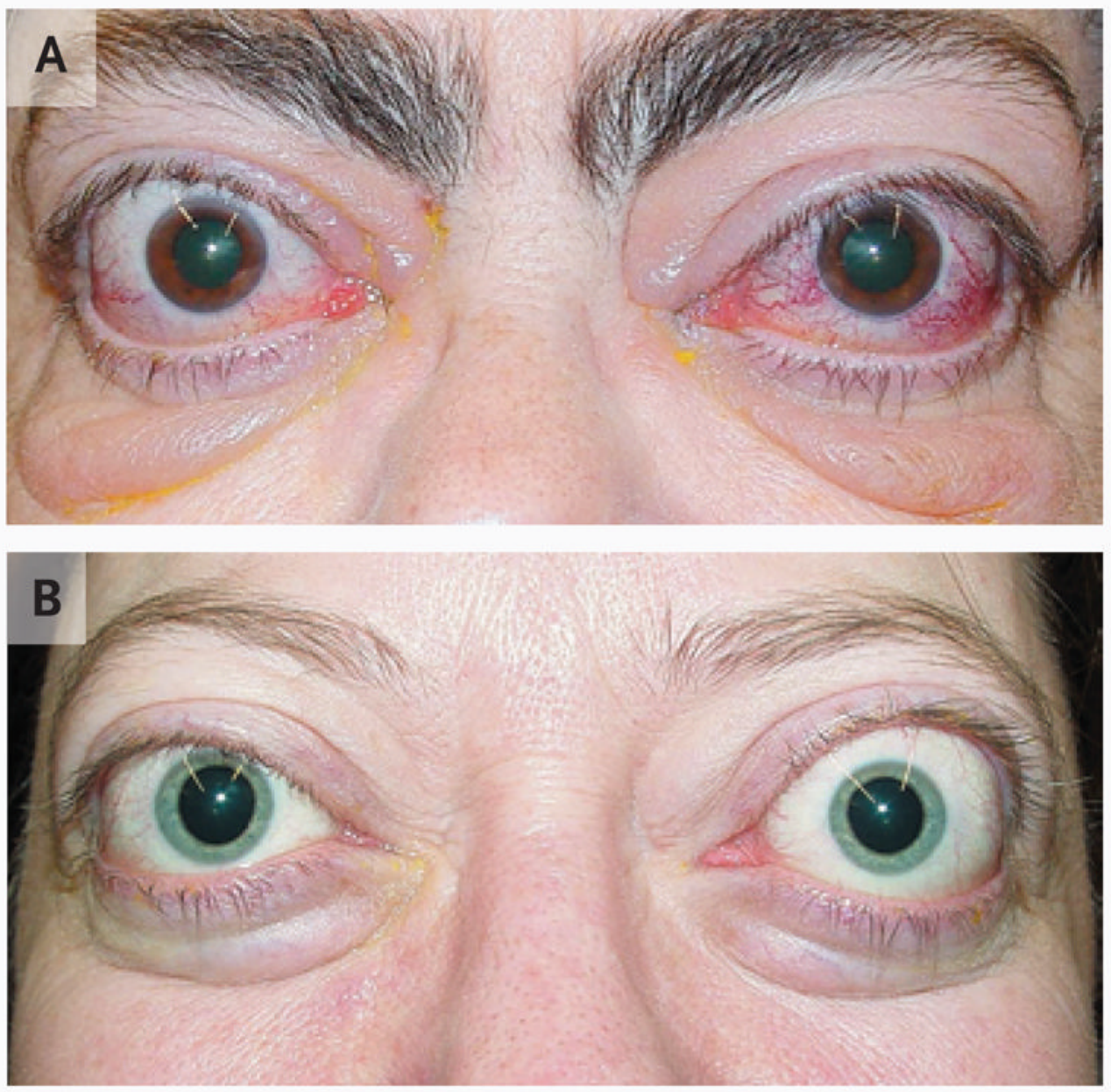

Figure 1. Patients with Graves' Ophthalmopathy

Panel A shows a 59-year-old woman with excess proptosis, moderate eyelid edema, and erythema with moderate eyelid retraction affecting all four eyelids. Conjunctival chemosis (edema) and erythema with bilateral edema of the caruncles, with prolapse of the right caruncle, are evident. Panel B shows a 40-yearold woman with excess proptosis, minimal bilateral injection, and chemosis with slight erythema of the eyelids. She also had evidence, on slit-lamp examination, of moderate superior limbic keratoconjunctivitis. 

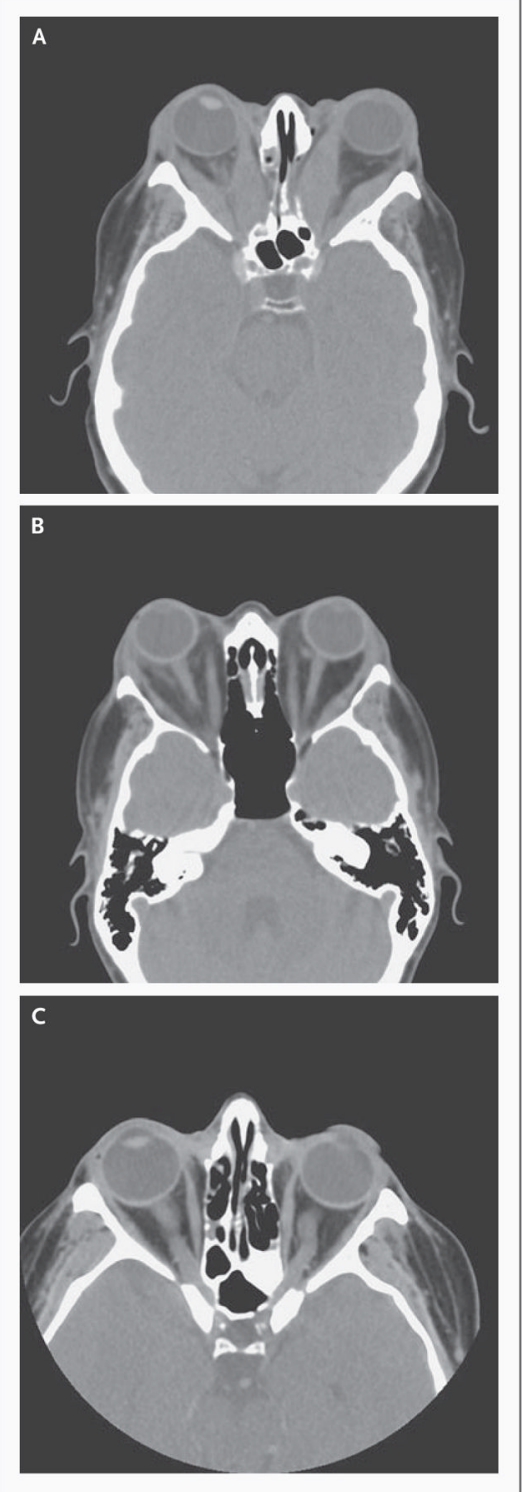

Figure 2. Computed Tomographic Scans of Patients with Graves' Ophthalmopathy and of a Normal Subject

Axial images of patients with Graves' ophthalmopathy reveal generalized enlargement of the extraocular muscles with marked bilateral proptosis (Panel A) and marked bilateral proptosis and asymmetric involvement of the extraocular muscles with expansion of the orbital fat bilaterally (Panel B). Normal orbits are shown (Panel C) for comparison. 


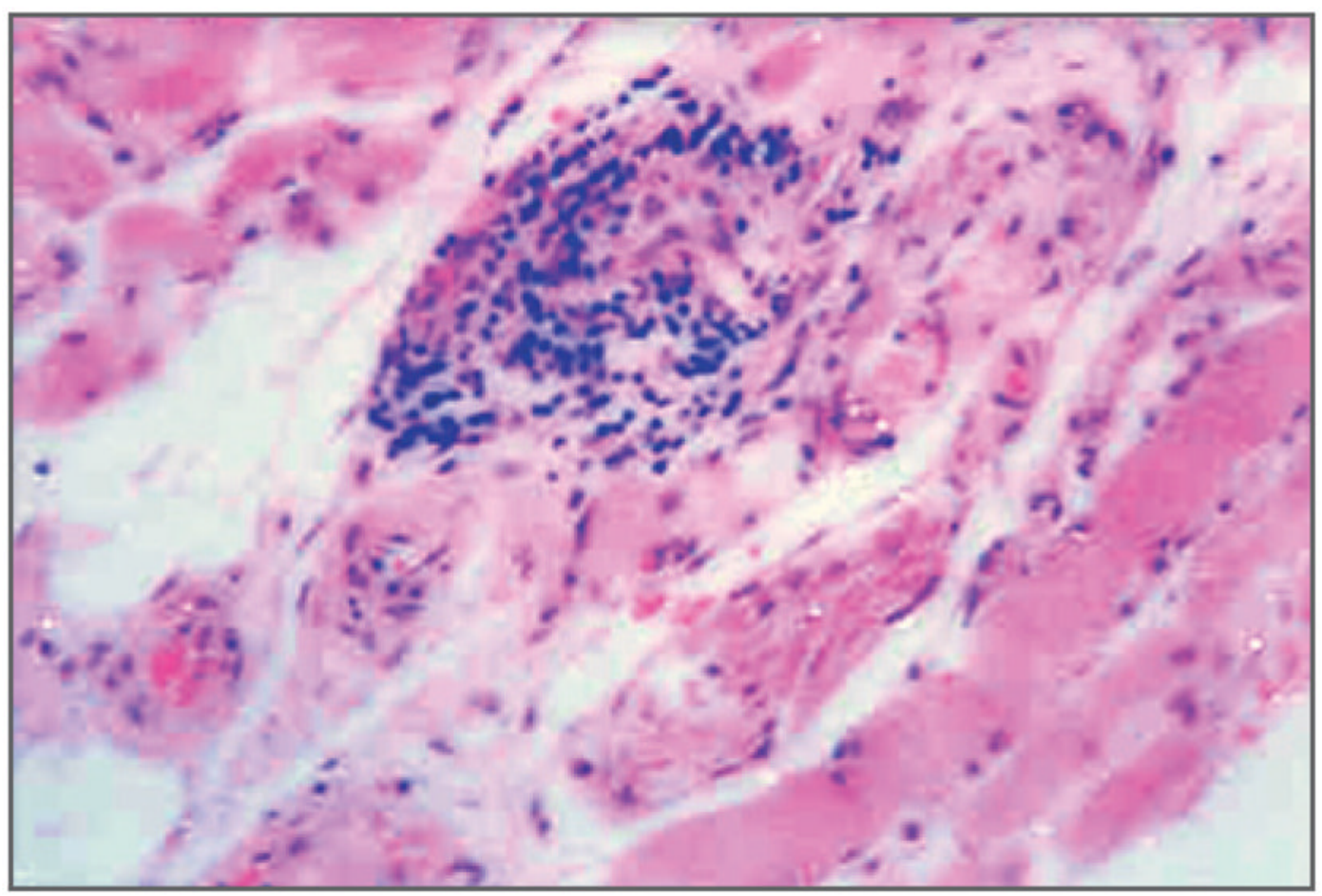

Figure 3. Histologic Appearance of Extraocular Muscle in Graves' Ophthalmopathy (Hematoxylin and Eosin)

The focal and perivascular interstitial inflammatory mononuclear cell infiltrate is in close association with intact striated extraocular muscle fibers widely separated by amorphous granular material. 


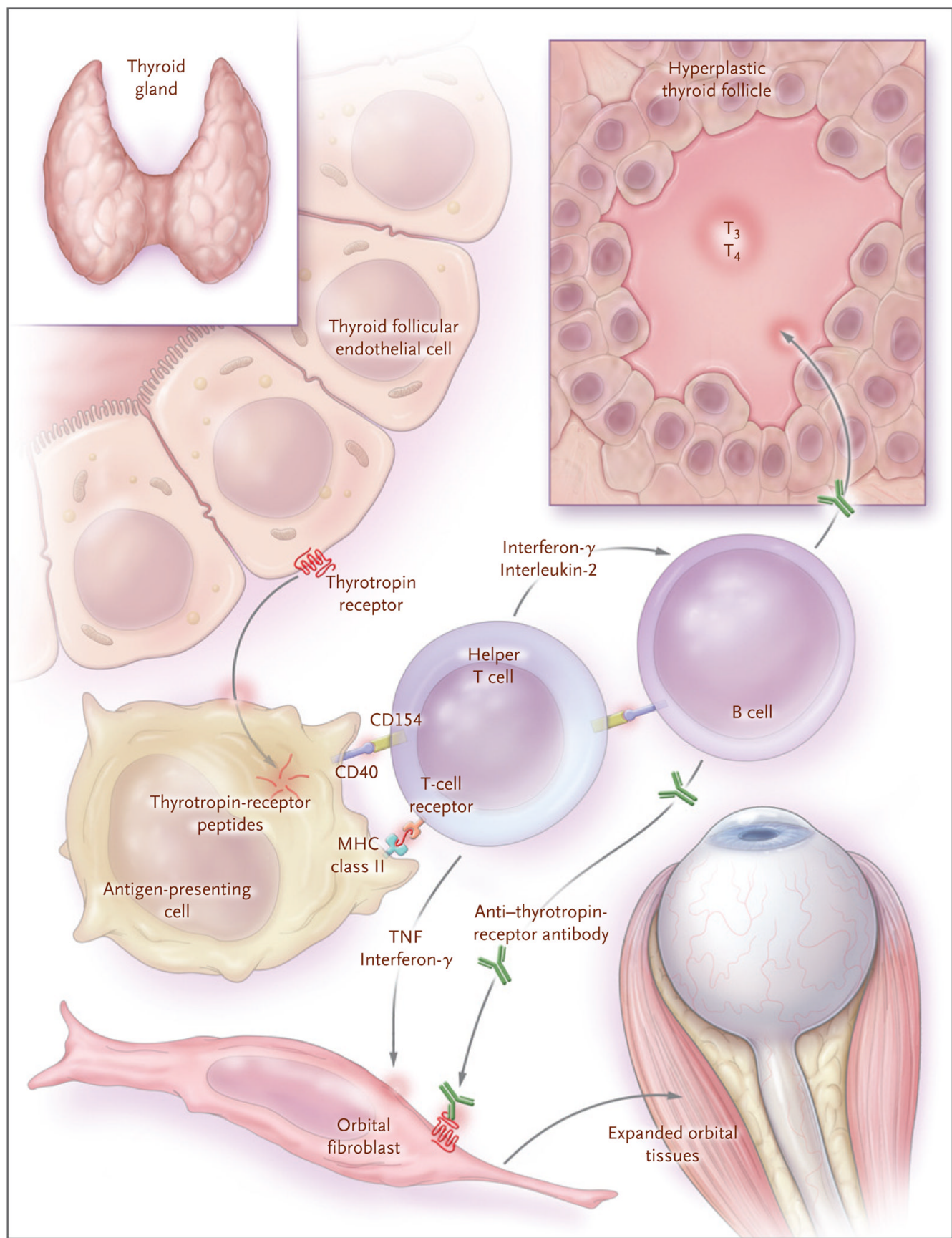

Figure 4. Model of the Initiation of Thyrotropin-Receptor Autoimmunity in Graves' Ophthalmopathy and Its Consequences

A failure of T cells to tolerate the thyrotropin receptor, for unknown reasons, allows for the development of autoimmunity directed against this receptor. The thyrotropin receptor is internalized and degraded by antigen-presenting cells that present thyrotropin-receptor peptides, in association with major histocompatibility complex (MHC) class II antigens, to helper T cells. These cells become activated, interact with autoreactive B cells through CD154-CD40 bridges, and secrete interleukin-2 and interferon- $\gamma$. These cytokines induce the differentiation of B cells into plasma cells that secrete anti-thyrotropin-receptor antibodies. These antibodies stimulate the thyrotropin receptor on thyroid follicular 
epithelial cells, leading to hyperplasia and increased production of the thyroid hormones triiodothyronine $\left(\mathrm{T}_{3}\right)$ and thyroxine $\left(\mathrm{T}_{4}\right)$. Anti-thyrotropin-receptor antibodies also recognize the thyrotropin receptor on orbital fibroblasts and, in conjunction with the secreted type 1 helper T cytokines interferon- $\gamma$ and tumor necrosis factor (TNF), initiate the tissue changes characteristic of Graves' ophthalmopathy. 


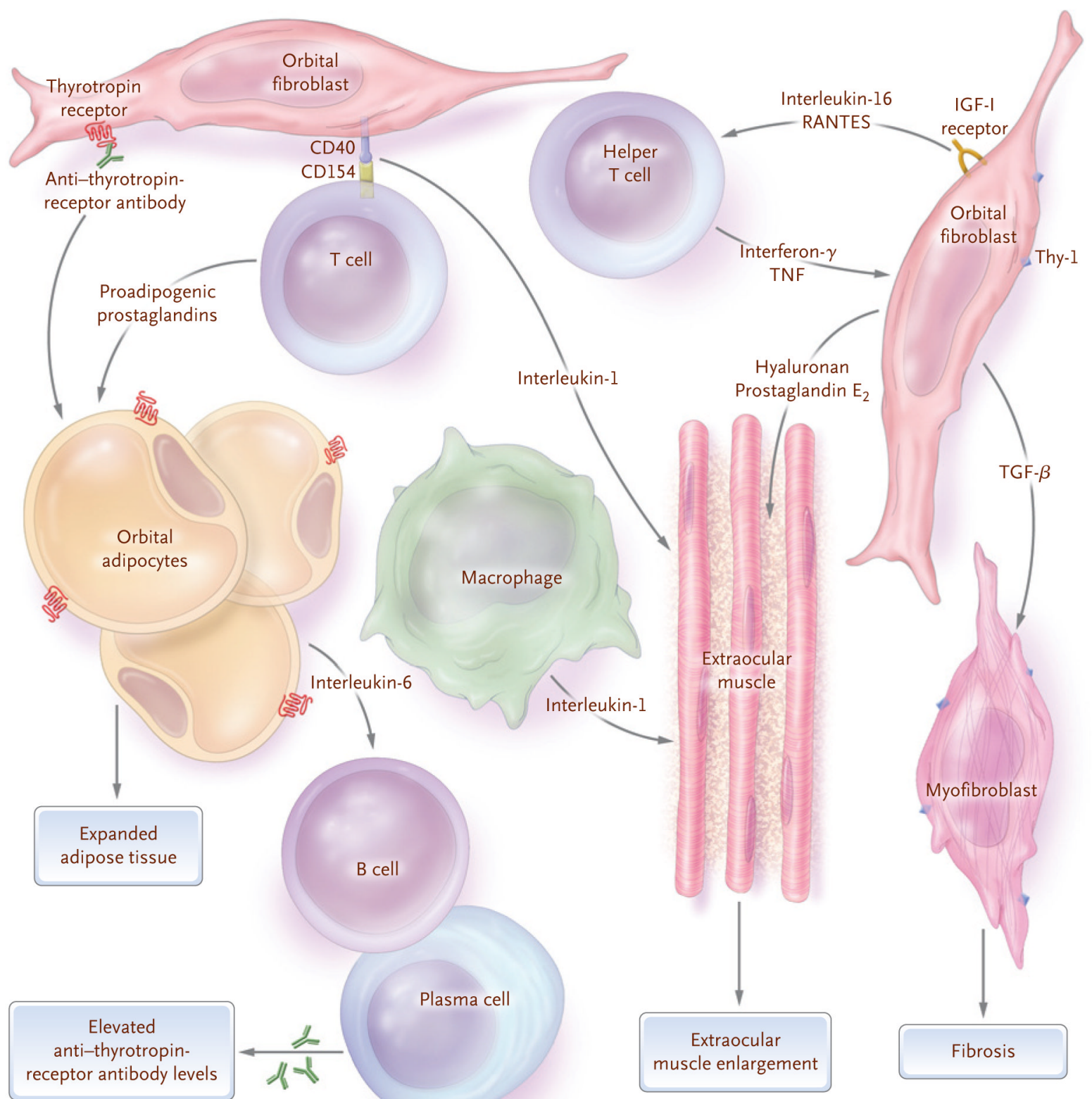

Figure 5. Model of Interactions between Orbital Fibroblasts and the Autoimmune Process Leading to the Tissue Changes Characteristic of Graves' Ophthalmopathy When activated by anti-thyrotropin-receptor antibodies, a subgroup of orbital fibroblasts (termed preadipocytes) begins to differentiate into adipocytes with increased thyrotropinreceptor expression, while others bearing the antigen Thy-1 are stimulated by cytokines, including interferon- $\gamma$ and tumor necrosis factor (TNF), to increase their production of hyaluronan. Similarly, stimulation of the insulin-like growth factor receptor (IGF-I receptor) expressed on orbital fibroblasts results in the secretion of the chemokines interleukin-16 and RANTES (regulated upon activation normal T-cell expressed and secreted), which enhance recruitment of activated $\mathrm{T}$ cells and other mononuclear immune cells into the orbit. The expression of CD154 in T cells allows for their direct interaction with orbital fibroblasts 
through the formation of CD40-CD154 bridges, resulting in fibroblast production of interleukin-1. Activated type 1 helper T cells in patients with early Graves' ophthalmopathy produce interferon- $\gamma$ and TNF, and resident macrophages secrete interleukin-1. These cytokines stimulate orbital fibroblasts to produce high levels of prostaglandin $E_{2}$ and hydrophilic hyaluronan that accumulates between the intact extraocular muscle fibers and within the orbital adipose tissues to enlarge the volume of these tissues. Activated T cells in patients with Graves' ophthalmopathy also produce proadipogenic prostaglandins that stimulate preadipocytes to differentiate into mature fat cells, further expanding the tissue volume. Adipocytes and fibroblasts produce interleukin-6, which augments B-cell maturation and increases the production of anti-thyrotropin-receptor antibodies by plasma cells within the orbit. Orbital fibroblasts also produce transforming growth factor $\beta$ (TGF- $\beta$ ), which stimulates both production of hyaluronan and differentiation of the Thy-1+ subgroup into myofibroblasts that participate in the development of fibrosis, especially in late stages of the disease. 


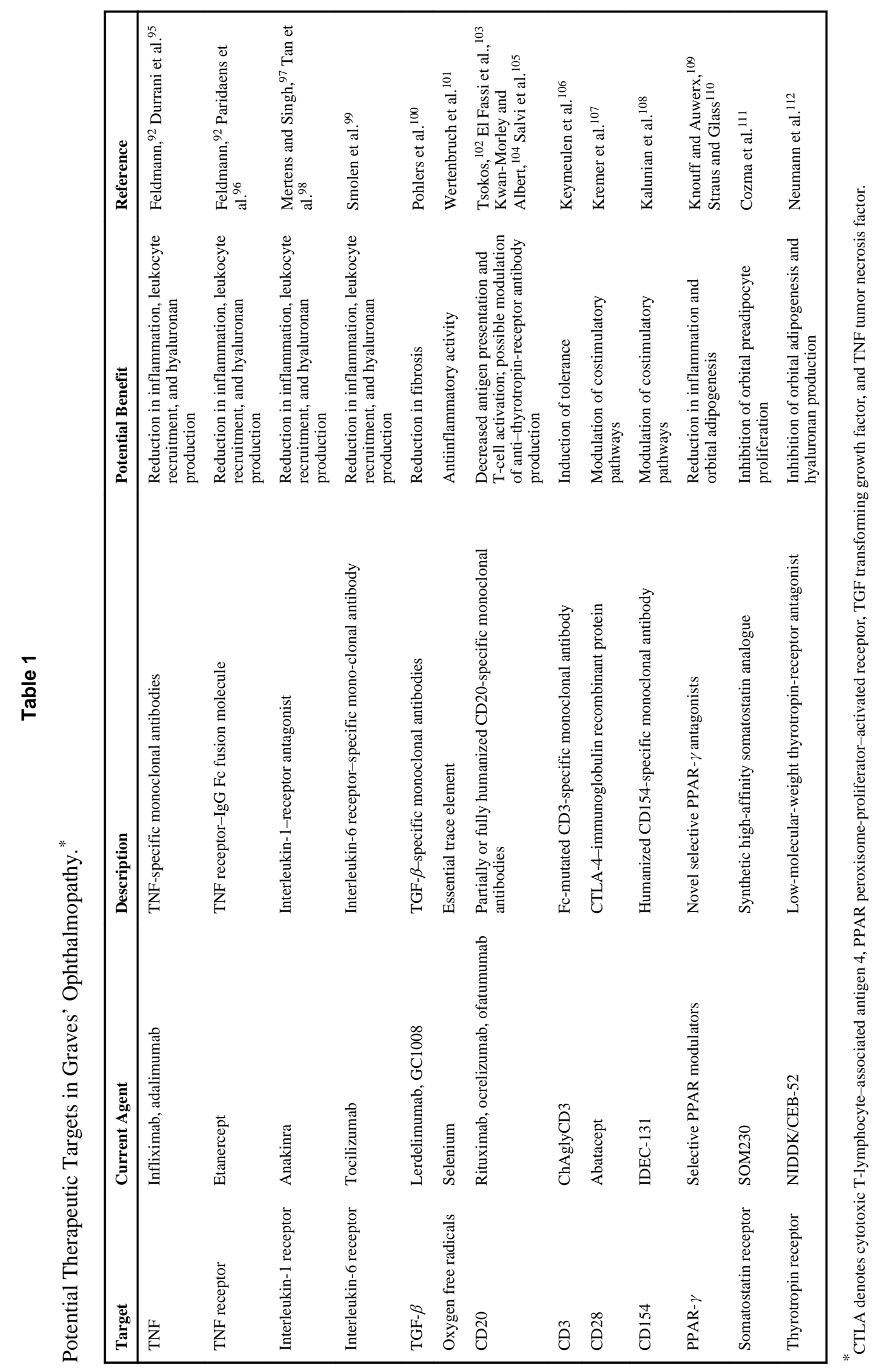

N Engl J Med. Author manuscript; available in PMC 2014 January 25. 